\title{
EFFECT OF PROSTAGLANDIN D2 ON PAIN AND INFLAMMATION
}

\author{
Tsuyako OHKUBO, Manabu SHIBATA, Hiroshi TAKAHASHI \\ and Reizo INOKI* \\ Departmerıt of Pharmacology. Fukuoka Dental College. Sawara-ku. \\ Fukuoka 814-01, Japan \\ * Department of Pharmacology, Osaka University Dental School. \\ Kita-ku, Osaka 530. Japan
}

Accepted November 10, 1982

Various studies about the role of the prostaglandin ( $P G$ ) $E$ and $F$ series in the pain and inflammatory reactions have been reported. However, there are few reports concerning these actions of $\mathrm{PGD}_{2}(1)$, one of the arachidonic acid metabolites that is similar to $P G E_{2}$ and $F_{2 a}$. In chicken urate crystal arthritis, $P_{G} D_{2}$ was by far the prevailing $P G$ in the exudates, reaching levels up to 10 times those of $P G E_{2}$ (2). In addition. Nugteren and Hazelhof reported that in many tissues. D prostaglandins were the main products of the endoperoxide breakdown (3). Therefore, in this paper, the involvement of $\mathrm{PGD}_{2}$ in the development of hyperalgesia and the inflammatory reaction was also studied in comparison with $\mathrm{PGE}_{1}$ and $\mathrm{E}_{2}$.

Male ddY strain mice (20-22 g) and male Wistar strain rats (100-110 g) were used. PGs used were supplied by Ono Pharmaceutical Co., Ltd. To test the hyperalgesic action of $\mathrm{PGD}_{2}$, the $\mathrm{ACh}$ - and bradykinin (BK)-writhing tests were used. PGs were administered i.p. $10 \mathrm{~min}$ before injection of $\mathrm{ACh}$ and BK. All drugs injected i.p. were dissolved in $0.2 \mathrm{ml}$ of $0.9 \% \mathrm{NaCl}$ solution. Various doses of $\mathrm{ACh}$ were injected i.p., and the ED50 value of $\mathrm{ACh}$ that elicited writhing was determined. In the ACh- and BKwrithing tests, the number of mice showed writhing response was measured during a $10 \mathrm{~min}$ period after $\mathrm{ACh}$ and $\mathrm{BK}$ injection. In case of testing the central action of PGs on pain sensitivity. $P G s$ dissolved in $0.9 \%$
$\mathrm{NaCl}$ solution were injected intracerebroventricularly (i.c.v.) in a volume of $5 \mu$. Five min after i.c.v. injection of PGs, pain sensitivity was measured in three ways: hotplate, Haffner's and acetic acid-writhing tests. In order to investigate the role of $\mathrm{PGD}_{2}$ in the inflammatory reaction, the paw edema test was used. Various doses of PGs dissolved in $0.1 \mathrm{ml}$ of $0.9 \%$ saline were injected into the right hind paw of rats, and the edema was measured by a mercury displacement manometry for $3 \mathrm{hr}$ after the injection. Furthermore, in order to test whether $\mathrm{PGD}_{2}$ could potentiate the inflammatory action, paws were pretreated with $P G s 10 \mathrm{~min}$ before subplantar injection of BK.

Table 1 shows the effects of $\mathrm{PGD}_{2}(1 \mu \mathrm{g} /$ $\mathrm{kg}$ ) pretreatment on $\mathrm{ACh}$ - and BK-writhing. The maximal doses of PGs, which did not cause writhing when given alone, were used. $P G D_{2}$ shifted the ED50 value of $A C h$ to a low dose similar to $P G E_{1}$ and $P G E_{2}$. Giving $B K$ alone (1, 0.1 or $0.01 \mathrm{mg} / \mathrm{kg}$ i.p.), manifestation of writhing was 20,10 or $0 \%$. respectively. When BK was injected in combination with $\mathrm{PGD}_{2}$, marked potentiation was observed at a BK dose of $0.01 \mathrm{mg} /$ $\mathrm{kg}$. In the cases of higher doses of BK. however, the number of writhings decreased rather than being the same as that obtained by $B K$ alone. A similar effect was obtained by mixtures containing $P G E_{1}$ or $P G E_{2}$.

The change of pain threshold by i.c.v. injection of $\mathrm{PGD}_{2}$ was investigated (Table 2). 
Table 1. Effects of $\mathrm{PGD}_{2}, \mathrm{E}_{1}$ and $\mathrm{E}_{2}$ on $A C h$ - and $B K$-writhing in mice

\begin{tabular}{|c|c|c|c|c|c|c|}
\hline \multirow{2}{*}{$\begin{array}{l}\text { Pretreatment } \\
\text { drugs } \\
\text { (i.p.) }\end{array}$} & \multirow{2}{*}{$\begin{array}{c}\text { Dose } \\
(\mu \mathrm{g} / \mathrm{kg})\end{array}$} & \multirow{2}{*}{\multicolumn{2}{|c|}{$\begin{array}{c}\text { ED50 value of ACh } \\
\text { (Confidence limit) } \\
(\mathrm{mg} / \mathrm{kg})(\mathrm{a})\end{array}$}} & \multicolumn{3}{|c|}{$\begin{array}{c}\% \text { of mice showing a writhing response } \\
B K(\mathrm{mg} / \mathrm{kg}) \text { (i.p.) }\end{array}$} \\
\hline & & & & 1 & 0.1 & 0.01 \\
\hline Saline & & 0.64 & $(0.46-0.94)$ & 20 & 10 & 0 \\
\hline$P G D_{2}$ & 1 & 0.08 & $(0.03-0.17)$ & 0 & 30 & 40 \\
\hline$P G E_{1}$ & 0.1 & 0.21 & $(0.06-0.44)$ & 0 & 10 & 60 \\
\hline$P G E_{2}$ & 1 & 0.11 & $(0.02-0.38)$ & 0 & 10 & 40 \\
\hline
\end{tabular}

Manifestation of the writhing response was observed during a 10 min period after ACh or BK injection. (a) None of these dose-response relationships differed significantly from linearity, and those from the experiments with PGs did not devite significantly from parallelism with the saline-treated control. (b) Each group included 10 mice.

Table 2. Effects of i.c.v. injection of $P G D_{2}, E_{1}$ and $E_{2}$ an pain sensitivity in mice

\begin{tabular}{|c|c|c|c|c|}
\hline & $\begin{array}{c}\text { Dose } \\
(\mu \mathrm{g} / \mathrm{kg})\end{array}$ & $\begin{array}{l}\text { Hot-plate test } \\
(\mathrm{sec}) \quad \text { (a) }\end{array}$ & $\begin{array}{l}\text { Haffner's test } \\
\begin{array}{ll}\mathrm{N} / 12 & \text { (b) }\end{array}\end{array}$ & $\begin{array}{l}\text { Acetic acid writhing } \\
\text { test }\end{array}$ \\
\hline Normal control & & $5.0 \pm 0.36$ & 0 & $18.7 \pm 2.66$ \\
\hline Saline & & $5.5 \pm 0.82$ & 0 & $15.6 \pm 2.18$ \\
\hline \multirow[t]{3}{*}{$\mathrm{PGD}_{2}$} & 0.5 & $5.3 \pm 0.42$ & 0.5 & $15.8 \pm 2.12$ \\
\hline & 5 & $6.4 \pm 0.61$ & 1.0 & $15.4 \pm 2.01$ \\
\hline & 50 & $7.6 \pm 0.56^{*}$ & 2.0 & $12.6 \pm 1.26^{*}$ \\
\hline Normal control & & $4.5 \pm 0.58$ & 0 & $26.6 \pm 2.47$ \\
\hline Saline & & $5.8 \pm 0.89$ & 0 & $20.9 \pm 3.78$ \\
\hline \multirow[t]{3}{*}{$P_{G}$} & 0.5 & $8.5 \pm 1.00$ & 2.5 & $16.9 \pm 4.28$ \\
\hline & 5 & $8.3 \pm 0.63^{*}$ & 4.0 & $17.5 \pm 3.24$ \\
\hline & 50 & $9.8 \pm 1.51^{*}$ & 4.0 & $9.0 \pm 2.44^{*}$ \\
\hline \multirow[t]{3}{*}{$\mathrm{PGE}_{2}$} & 0.5 & $4.8 \pm 0.60$ & 0 & $25.2 \pm 2.15$ \\
\hline & 5 & $5.0 \pm 0.58$ & 0 & $36.0 \pm 4.90^{*}$ \\
\hline & 50 & $3.6 \pm 0.38^{*}$ & 0 & $23.8 \pm 4.61$ \\
\hline
\end{tabular}

(a) Hot-plate test: Mice were placed on the hot-plate $\left(55 \pm 0.5^{\circ} \mathrm{C}\right)$ and latencies of their first response (licking the feet. jumping or rapidly stamping the feet) were recorded. Each value showed the mean \pm S.E. of 12 animals.

(b) Haffner's test: The pressure of $500 \mathrm{~g}$ on the tail root of the mouse was given, and the biting response was used as an index. Pain sensitivity was expressed as the ratio of the number of animals showing negative and false positive reaction (only false positive reaction was changed into 0.5 )/number tested $(n=12)$.

(c) Acetic acid-writhing test: Number of writhing responses occuring during a 10 min period after a lapse of the first $5 \mathrm{~min}$ after i.p. injection of $0.6 \%$ acetic acid $(0.1 \mathrm{ml} / 10 \mathrm{~g}$ body weight) was measured. Each value showed the mean \pm S.E. of 12 animals. "Significantly different from the saline control $(P<0.05)$

There was no significant difference between the saline control and the normal control (non-treated). Increase in doses of $\mathrm{PGD}_{2}$ from 0.5 to $50 \mu \mathrm{g} / \mathrm{kg}$ decreased the pain sensitivity dose-dependently with each method, but $P \mathrm{D}_{2}$ had a less potent analgesic effect than $P G_{1}$. Conversely,
$P G E_{2}$ caused an increase of pain sensitivity. $\mathrm{PGD}_{2}$ was injected into the hind paw of rats, and the potency for edema formation was compared with $P G E_{1}$ and $P G E_{2} . P G D_{2}$ (10, 100, $1000 \mathrm{ng}$ ) produced the paw swelling dose-dependently (data not shown). This inflammatory effect of $P G D_{2}$ was less 
potent than $P G E_{1}$ and $E_{2}$ and lasted for $a$ short time. Effects of the addition of various $P G s$ on the paw swelling induced by $B K$ (10 ng) were examined (data not shown). Each dose of PGs used had no greater effect than saline when given alone. However. pretreatment with $\mathrm{PGD}_{2}$ (1 ng) caused potentiation of the BK paw swelling. One twentieth ng of $P G E_{1}$ had a similar potentiating effect, but $\mathrm{PGE}_{2}(0.05 \mathrm{ng}$ ) gave no potentiation.

It was observed that $\mathrm{PGD}_{2}$ injected into a peripheral site elicited hyperalgesia in the ACh- and BK-writhing tests, similarly to $P G E_{1}$ and $E_{2}$. When $P G D_{2}$ was injected into the cerebral ventricle, it showed an analgesic effect. Thus there was the different result that $P G D_{2}$ was hyperalgesic peripherally and analgesic centrally. The same effect was reported on $B K(4,5)$ and substance $P(6,7)$. Pretreatment with the low dose of $\mathrm{PGD}_{2}$ (1 ng) resulted in potentiation of $B K$ paw swelling. However, $\mathrm{PGD}_{2}$ was about onetwentieth as potent as $P G E_{1}$. These results indicate that $\mathrm{PGD}_{2}$ appears to possess hyperalgesic action in the peripheral pain reaction and performs the roles of chemical mediator and potentiator in the inflammatory process.

\section{References}

1) Flower, R.J., Harvey, E.A. and Kingston, W.P.: Inflammatory effect of prostaglandin $D_{2}$ in rat and human skin. Br. J. Pharmacol. 56, 229-233 (1976)

2) Peskar, B.A. and Brune, K.: Prostaglandin $D_{2}$. The prevailing prostaglandin in an acute inflammation. Agents Actions 4, 260-266 (1979)

3) Nugteren, D.H. and Hazelhof, E.: Isolation and properties of intermediates in prostaglandin biosynthesis. Biochim. Biophys. Acta 326, 448-461 (1973)

4) Inoki, R., Kudo, T. and Hayashi, T.: Action of analgesics on the kallikrein-kinin system. Folia Pharmacol. Japon. 72, 519-530 (1976) (Abs. in English)

5) Inoki, R., Kudo, T., Oka, M. and Kotani, Y.: Analgesic action of biological active polypeptides following the intraveritricular administration. Japan. J. Pharmacol. 28, Supp. 169P (1978)

6) Stewart, J.M., Getto, C.J., Neldner, K., Reeve, E.B., Krivoy, W.A. and Zimmermann, E.: Substance $P$ and analgesia. Nature 262, 784$785(1976)$

7) Kotani, Y., Oka, M., Yonehara, N., Kudo, T. and Inoki, R.: Algesiogenic and analgesic activities of synthetic substance P. Japan. J. Pharmacol. 31, 315-321 (1981) 